\title{
Mind the gap: national and local partnership in the Irish public sector
}

\author{
Michael Doherty and Roland Erne
}

\begin{abstract}
This article uses case study data from a major Irish city council to investigate and explain public sector worker attitudes towards social partnership at local and national level. It is argued that the more sceptical attitudes to workplace partnership reflect structural differences between local and national arrangements, which have enabled public sector employers to use 'social partnership' as a constraint in the implementation process of a pre-determined public sector reform agenda.
\end{abstract}

\section{INTRODUCTION}

The period since 1987 has seen the conclusion of a succession of national social pacts between the Irish social partners. Since the mid-1990s the diffusion of partnership to workplace level has become an important objective of the agreements. While much has been written on the macro-effects of national partnership (Hastings et al., 2007; Mac Sharry and White, 2001), empirical studies of the actual effects of existing workplace partnership structures have been slower to emerge (cf. D'Art and Turner, 2002; Geary, 2008; Geary and Roche, 2006). Even rarer are accounts of the partnership process that explicitly incorporate both national and workplace levels. This may be understandable in the private sector context, where national deals place few obligations on employers beyond pay, but, as we will see, seems less explicable in relation to the public sector. In addition, the literature has primarily been concerned with the impact of partnership processes on the industrial relations (IR) actors, rather than on employees themselves.

This article uses case study data to investigate and explain differing public sector worker attitudes towards social partnership at local and national levels. The role of the public sector is crucial to any analysis of Irish social partnership. First, given that trade union density in the public sector is much higher than in the private sector, the public sector unions (in particular the state's second-largest union, the Irish Municipal Public and Civil Trade Union-IMPACT) have always had a key role in shaping and sustaining the process (Baccaro and Simoni, 2007). At workplace level, it is important to note that, although the development of workplace partnership struc-

$\square$ Dr. Michael Doherty is a lecturer in law in the School of Law and Government, Dublin City University, Dublin 9, Ireland. Dr. Roland Erne is a lecturer of comparative and international employment relations in the UCD Business School, University College Dublin, Belfield, Dublin 4, Ireland. Correspondence should be addressed to Dr. Michael Doherty, School of Law and Governance, Dublin City University, Dublin 9, Ireland; email: michael.doherty@dcu.ie 
tures has been promoted in the national deals since the mid-1990s, initiatives have been voluntarist in nature, and the result has been a low incidence of workplace partnership structures in the private sector; these are much more common in the public sector (Geary, 2006; O'Connell et al., 2004). ${ }^{1}$ Finally, a key focus of our analysis is the interlinking of the partnership and public sector modernisation agendas which, we will argue, is vital to explaining worker attitudes to public sector partnership.

Our data suggests that, while national agreements are perceived quite positively, public sector workers' attitudes towards local partnership arrangements are much more sceptical. Likewise, local partnership arrangements seem to be much more unstable than national pacts (O'Connell et al., 2004). It has been suggested that the difficulties of local partnership are linked to the more militant attitudes of workers, middle-management and worker representatives. Our analysis of partnership structures and examination of worker attitudes however proffers a different explanation focusing on how workplace partnership in the public sector has been used as a means of facilitating the implementation of a pre-determined management reform agenda.

\section{CAN'T WE ALL JUST GET ALONG? PARTNERSHIP AND PUBLIC SECTOR REFORM}

The Irish social partnership process has attracted significant attention in the IR literature, with a significant portion of this focused on 'accounting' for the Irish case (Auer, 2000; Baccaro, 2003; Roche, 2007), as Ireland, with its Anglo-Saxon IR tradition, was seen as not possessing the classical 'institutional preconditions' (Baccaro, 2002) for corporatist deals. Thus, the Irish process has been variously categorised as an example of: 'deliberative governance' (O’Donnell, 2000); 'competitive corporatism' (Roche, 2007); an 'unorthodox system of institutional complementarities' (Teague and Donaghey, 2009); and from a critical perspective, union incorporation (Allen, 2000) and the emasculation of Parliamentary democracy (O'Cinnéide, 1998). The intention here is not necessarily to weigh in on this debate, but to flag a possible alternative way of viewing the partnership process as it applies to the public sector, focusing on the (to date somewhat neglected) relationship between partnership and public sector reform.

For both critics and proponents of the partnership process, with its high-level political exchange among union elites, employers and government, and the tendency under bargained corporatism for power to shift towards the union centre, a fundamental concern relates to the exclusion of participation by workers and union members at the level of the workplace. Ireland (unlike many European countries) does not provide for workplace participation in the form of statutory works councils. As the national process developed, therefore, attempts intensified to develop partnership at workplace level and thus link up the enhanced role for trade unions at national level with increased influence for workplace worker representatives. The Partnership 2000 and Programme for Prosperity and Fairness (PPF) agreements defined 'enterprise partnership' as an active relationship between stakeholders based on a recognition of their common interest in the prosperity of the enterprise, which involves common ownership of the resolution of challenges. Nine areas were identified in which the

\footnotetext{
${ }^{1}$ Note, too, recent evidence that the overwhelming majority of workplace partnership agreements in the UK, albeit in a very different institutional setting, are in the public sector (Bacon and Samuel, 2009). 
concept would be particularly apposite (e.g. work organisation, financial involvement; see paragraph 9.12 of Partnership 2000).

Unlike the statutory works council model, the national agreements have used a voluntary framework approach (Geary and Roche, 2005) to encourage and promote the 'bottom-up' development of partnership at local level and allow partnership to be tailored to local needs and preferences. The discourse of workplace partnership, therefore, is framed in terms of solidarity, inclusiveness, participation and workplace democracy. This is particularly true of the focus of this article, local government. For example, the Deepening Partnership in Local Government Strategic Plan 2003-05 states that:

the vision for partnership in local authorities is for it to become the established way of doing business, which would involve management, unions and staff at all levels in addressing a wide range of issues of strategic and operational importance and in delivering positive outcomes to all stakeholders... (paragraph 4.1).

Irish social partnership thus created a two-tier industrial relations framework that operates at national and workplace levels. However, whereas corporatist arrangements traditionally established a national framework of entitlements and obligations to guide how employers and employees should behave at work, social partnership in the Irish case did not display such interlocking connections between the two levels. Apart from the centrally agreed obligation to pay moderate wage increases, Irish social pacts placed few constraints on private sector firms, granting them almost 'complete autonomy to pursue corporate strategies of their choosing at the company level' (Teague and Donaghey, 2009; 67). Accordingly, whenever scholars referred to partnership arrangements at workplace level, they referred to Anglo-Saxon voluntarist frameworks rather than the corporatist and statutory settings that govern workplace relations in continental Europe (Geary, 2008; Roche, 2007).

The situation in the public sector, however, has been somewhat more complicated. While the national framework agreements were not binding, they undoubtedly had more 'teeth' as they explicitly required the parties to fuse the management of public service reform with the establishment of workplace partnership arrangements (Geary, 2008; 563). The aspiration to shift to a partnership approach in the public sector comes at a time when public administration (particularly, but not exclusively, in the Anglo-Saxon context) continues to be subject to what Du Gay (2008: 336) refers to as 'extraordinary degrees of turbulence'. There has been mounting pressure for the public sector to be more 'efficient' and 'cost-effective', which has often resulted in heightened managerialism and the blurring of boundaries between the experience of public and private businesses (Pate et al., 2007).

According to the Organisation for Economic Co-operation and Development (OECD), Ireland has 'significantly advanced along a New Public Management (NPM) continuum' (OECD, 2008: 18) of public sector reform first outlined in the Strategic Management Initiative (SMI) of 1994 and expanded through Delivering Better Government in 1996 (a specific framework for reform of local authority structures, Better Local Government, was also published in 1996). The SMI explicitly brought the social partners on board to input into the reform process (OECD, 2008). In Ireland, as in most European countries, public sector reform efforts have been centred around the need to revamp performance appraisal systems and create more effective tools for 'performance management', based on objective setting, feedback and performancelinked rewards (Roche, 1999). As a result, all national agreements since 1996 have 
made the payment of agreed salary increases for public employees dependent upon co-operation with satisfactory implementation of the modernisation agenda set out in the agreements (see, e.g. paragraph 27.18 of Towards 2016). Performance Verification Groups (PVGs) for different sectors (health, local government, etc.) were established to make recommendations as to whether or not pay increases should be made. In all cases, it was envisaged that the process of reform and the successful implementation of the change and innovation processes outlined in the national agreements would be accompanied by 'robust workplace partnership' structures 'characterised by high levels of employee and union involvement with management' (NCPP, 2005: 30).

Thus, we can see a clear interlinking of public policy agendas. The process of public sector reform is outlined in strategic documents prepared in consultation with the social partners and in the national partnership agreements themselves. A framework for workplace partnership structures is also outlined in the national agreements. These are to be established with a view to the implementation and management of reform and change at workplace level in accordance with the principles underlying social partnership; solidarity, inclusiveness, participation and workplace democracy.

Despite the promotion of workplace partnership, evidence suggests its penetration appears relatively limited (Geary, 2006; O'Connell et al., 2004). Some authors have suggested that a key problem is that of 'buy-in' by relevant stakeholders (Teague, 2004). Managers may fear that sharing information will undermine their authority, while trade union representatives may struggle to move away from traditional confrontational behaviour. Others suggest that a key problem is that partnership initiatives are often 'imposed' on workers by management and unions and do not connect with salient employee concerns (Tailby et al., 2004).

However, it might be expected that, as the workplace partnership process is framed in a discourse of inclusion and participation, public sector staff would identify more strongly and positively with partnership (where it exists) at workplace level rather than the more distant, high-level arena of national level social partnership. This research investigated the views of stakeholders (and in particular, ordinary employees) in a typical public service workplace, a local authority, on both national and workplace level partnership.

\section{COMPLEXITY NOW: LOCAL GOVERNMENT REFORM}

A local authority workplace (Urban City Council²) was chosen as a means of looking in more depth at employee views of public sector partnership for a number of reasons. First, employees there were all members of the biggest public service trade unionIMPACT, which has been an enthusiastic supporter of, and has had a key role in, the partnership process. Second, the council has the same workplace partnership structures that exist in other parts of the public sector (the universities, for example). Third, the council was, and continues to be, subject to the public service modernisation agenda and, indeed, the local government sector has been lauded as a 'trail-blazer' in respect of elements of this agenda (e.g. independent monitoring and verification of performance reporting). ${ }^{3}$ Furthermore, and crucially for the analysis here, local government has been identified as a sector "where there has been a strong emphasis on

\footnotetext{
${ }^{2}$ Guarantees of anonymity were given, so all names used are pseudonyms.

${ }^{3}$ See the Service Indicators in Local Authorities 2004 Report available at http://www.lgmsb.i.e./upload/ documents/ServiceIndicators2004.pdf.
} 
deepening social partnership for implementing change' (OECD, 2008: 116). Lastly, the council should present a relatively benign environment for partnership structures to be established as, for reasons outlined below, we hypothesised that the employees in question would be likely to be well-disposed to the concept of workplace partnership. Before going on to describe the case study workplace in detail, it is necessary to look more closely at reform in the local government sector in the light of the general discussion of public sector reform above.

The Local Authority National Partnership Advisory Group (LANPAG) was set up as the national partnership body that represents the local authority employers and trade unions. It is made up of a number of nominees of the employer body, the Local Government Management Services Board (LGMSB) and the trade unions. In 1999, LANPAG agreed a framework document for partnership within local authorities. Since then its role has been to co-ordinate, advise and support each local authority in devising its partnership approach, and to promote a two-way flow of communication on partnership findings and developments. LANPAG also administers funding for the employment of workplace partnership facilitators, provision of training and facilitation of meetings. Performance indicators for the local authority sector, set out in the PPF and Sustaining Progress national agreements, were also agreed through LANPAG. The establishment of Performance Verification Groups (PVGs) is handled at national level by the LGMSB.

In Ireland, a key component of reform is the Performance Management Development System (PMDS) for local authorities agreed by the social partners under the Sustaining Progress agreement. Section 26 of Sustaining Progress ${ }^{4}$ sets out a mechanism for verifying performance involving LANPAG, the Local Government Performance Verification Group (LGPVG), the Secretary-General of the Department of Environment, Heritage and Local Government, and the Local Authority National Council.

This is a wondrously complicated process. Initially, an action plan is agreed by LANPAG. The action plan is then approved by the LGPVG and issued to each local authority by LANPAG. Each local authority head then provides a report on the progress achieved in respect of the various commitments. This report includes any 'observations' made by the local partnership committee. When the individual local authority reports are received by LANPAG, these reports and a sectoral report, are submitted to the Secretary-General of the Department. Having considered these reports, the Secretary-General will submit her/his own assessment of progress to the LGPVG. The LGPVG will then carry out its verification process, which includes site visits to individual local authorities, and a report with recommendations, is sent to the Secretary-General for consideration. At this stage, if the Secretary-General is satisfied with progress, she/he will approve payment of the increases due. If not, she/he may unilaterally decide to refuse to sanction payments or may defer payments.

This process of reform and verification applies in substantially the same manner across the entire public service (although, as noted, the local government sector is seen as being in the vanguard of the change process). To investigate further the links between the reform and partnership processes a typical local authority workplace was chosen as a case study location.

\footnotetext{
${ }^{4}$ See also section 33 of Towards 2016.
} 


\section{INVESTIGATING LOCAL AUTHORITY PARTNERSHIP}

Urban City Council employs approximately twelve hundred staff in various clerical/ administrative, professional and manual grades. Around five hundred staff members are 'outdoor' and they work in various depots around the city. The focus here is on the 'indoor' staff, predominantly clerical and administrative workers, all of whom are members of IMPACT and based in the Transportation and Environment departments.

The membership of the indoor local government branch of IMPACT is whitecollar, and industrial action among indoor staff is historically rare. IMPACT is seen as a union that frequently resorts to the state dispute resolution machinery (the Labour Court, Rights Commissioners, etc.). This type of trade unionism may be described as being the preserve of better-qualified and more professional employees and is based more on upholding the growing array of individual workers' legislative rights, more geared to consultative processes and, arguably, less dependent upon collective action in the traditional sense (Wallace et al., 2004). Thus, it might be expected that such workers would be more amenable to partnership than those in more 'militant' workplaces (or indeed, than their blue-collar, outdoor colleagues).

The research (consisting of semi-structured interviews, documentary analysis, and a survey questionnaire) was carried out in 2004 during four day-long visits to the council headquarters. Initial interviews took place with the deputy head of human resources (HR), the local union representative and the local partnership facilitator. Each was asked to suggest employees to be interviewed and each interviewee, in turn, was asked to nominate another candidate ('snowballing'). All employees were interviewed at the workplace. In all, interviews with ten staff members (seven females and three males) lasting approximately 45 minutes each were conducted, recorded and transcribed. In addition, 100 survey questionnaires were randomly distributed in the two departments and 32 responses were received.

The sample therefore is small and, as with any case study research, there are distinctive circumstances that apply to this workplace so that questions about the lack of generalisability do arise (Black et al., 1997). However, the detailed examination of processes in an organisational context and knowledge about the processes underlying the behaviour and its context can help to specify the conditions under which the behaviour can be expected to occur. The basis of any generalisation, therefore, is not primarily about the typicality of the organisation (notwithstanding the factors typical of the sector-IMPACT's presence, employee profile, archetypical partnership structures and an advanced reform agenda-outlined above), but the existence of particular processes, which may influence behaviours and actions in organisations (Hartley, 1994).

The partnership facilitator, based in the council since 2000, outlined at length the setting up and operation of the partnership process there. The initial step (four years prior to the research) was to set up a partnership committee with representatives of unions and management, chaired by the facilitator. Training was brought in for the committee, funded by LANPAG, and based around consensus and problem-solving techniques. One of the initial aspects of the process was a series of partnership briefing sessions (a 'Workplace Review'), which all staff members were invited to attend. Employees were broken into small groups, mixed with regard to department and grade, and asked to raise issues with which they felt partnership should deal. These were collated and a database formed. The partnership committee then began to attempt to address the issues raised through the establishment of various sub- 
committees. As noted above, the committee also has a role in the implementation of the reform agenda and verification processes.

\section{PARTNERSHIP: THE VIEW FROM BELOW}

Employee respondents were strongly of the view that general social and economic conditions, and pay and conditions for workers in the Irish economy and in the council itself had improved as a result of the national partnership agreements (Table 1). One female employee pointed out that her primary rationale for union membership was: 'the pay agreements coming into force at the moment. We're voting yes, yes, yes!'. The interview data generally revealed strong support for the process, especially in terms of pay outcomes: 'I would absolutely be in favour of partnership. How could you not be?' (Cian).

Survey respondents were also asked to consider if trade unions had a greater role in influencing state social and economic policy. Two-fifths of respondents (thirteen) felt that this was the case while just one responded negatively. ${ }^{5}$

Broadly speaking, the results suggest a quite positive view of national partnership. When the focus shifts to the level of the workplace, however, the picture is somewhat different (Table 2). Respondents were asked for their views on whether greater cooperation between employees and employers at the workplace was evident in the partnership era. A large number was undecided on this question, while opinion was

Table 1: As a result of social partnership, there are improved

\begin{tabular}{lcccc}
\hline & $\begin{array}{c}\text { Strongly } \\
\text { agree/ } \\
\text { Agree }\end{array}$ & Undecided & $\begin{array}{c}\text { Disagree/ } \\
\text { Strongly } \\
\text { disagree }\end{array}$ & Total \\
\hline $\begin{array}{l}\text { Socio-economic conditions for } \\
\text { Irish workers }\end{array}$ & 24 & 4 & 4 & 32 \\
Pay/conditions for Irish workers & 27 & 4 & 1 & 32 \\
Pay/conditions at my workplace & 24 & 5 & 3 & 32 \\
\hline
\end{tabular}

$n=32$.

Table 2: As a result of social partnership, there is

\begin{tabular}{lcccc}
\hline & $\begin{array}{c}\text { Strongly } \\
\text { agree/ } \\
\text { Agree }\end{array}$ & Undecided & $\begin{array}{c}\text { Disagree/ } \\
\text { Strongly } \\
\text { disagree }\end{array}$ & Total \\
\hline $\begin{array}{c}\text { Greater employee/employer } \\
\text { co-operation at the council }\end{array}$ & 9 & 14 & 9 & 32 \\
$\begin{array}{c}\text { Greater union influence on management } \\
\text { policy at the council }\end{array}$ & 5 & 11 & 16 & 32 \\
\hline
\end{tabular}

$n=32$.

${ }^{5}$ It should be noted that more than half of respondents (eighteen) were undecided. 
evenly split among the remainder. More worrying, from a trade union perspective, is the fact that employees clearly feel that unions have not gained more influence at workplace level.

The interview data revealed that while respondents believed that workplace partnership in principle was a good idea, and that the Workplace Review had been a worthwhile exercise, in practice the process had little positive impact on their working lives:

There would be an awareness that there are partnership groups and that. We've gone to various workshops about it, we've done questionnaires about how happy we are in the workplace and do we need change and our colleagues and things like that . . . I can't say there has been any difference though (Deirdre).

Overall the interview and survey data indicate a greater approval of national partnership. This was unequivocally the view of Brendan, the local union representative:

(Partnership) at a macro-level where (IMPACT's General Secretary) talks to (the Minister) and his mandarins works very well. I can picture them all having a grand chat about pensions and all that stuff, important stuff really and it works. But there is no real partnership once you get outside of the macro deals.

As noted above, this is somewhat counter-intuitive given the discourse of workplace partnership. Furthermore, this is so despite the fact that the evidence seemed to show that workplace partnership has targeted issues of concern to the council's employees. The key issues exercising staff that emerged from the fieldwork were the lack of organisational communication, problems of communication with management, the lack of performance recognition and feedback, and issues around promotion and mobility. The issues prioritised in the council's 2003-05 Strategic Plan closely mirrored these; the development of staff fora, the breakdown of barriers between grades, improved staff-manager communications and a new system of staff recognition/mobility. Moreover, the 'buy-in' issue alluded to above did not feature to any great degree; according to the partnership facilitator, while initially some reservations about the process surfaced on the management side in particular, four years on from its inception the management nominees were drawn from the upper echelons of the council. Furthermore, the local union representative's objection to the process centred, not on any feeling that his (and the local union's) role was being 'displaced' (Geary and Roche, 2006), but that the partnership process was being invoked by management only on a selective basis (see below).

\section{REFORM AND RHETORIC-EXPLAINING THE NATIONAL-LOCAL DIVIDE?}

The small-scale data here reflects national evidence that suggests workplace partnership in the public sector is struggling to establish itself and that there is a concern about the lack of successful outcomes (Geary, 2006; O'Connell et al., 2004; Williams et al., 2004). To explain this we need to take a closer look at distributive and structural issues surrounding national and workplace partnership. In particular, we believe, a persuasive explanator for the less emphatic support for workplace partnership among employees could be its use as a vehicle of public sector reform, as evidenced by the rise of managerialist 'rituals of verification' in the local government sector (Power, 1997). 
A key element of this relates to the verification process outlined above. We saw that, while wage increases are negotiated centrally (and take careful note of prevailing macro-economic trends to do with inflation, national competitiveness, etc.), their delivery is dependent on events and progress at local level. This peculiar structure entitles the Secretary-General of a government department, upon recommendation of a technocratic verification body, to unilaterally suspend the implementation of agreed wage increases under the national partnership agreement for a particular local unit, where the unit's progress report fails to meet the performance targets of the public sector modernisation action plan. This action plan and progress report system effectively turns the local partnership committee into a managerialist body that enforces and records local trade union concessions, such as the introduction of an individualised PMDS, which are necessary to obtain the wage increases under the national agreement.

An extract from the Urban City Council Action Plan/Progress Report from the time the fieldwork was carried out is reproduced in Appendix A. The 'check list' nature of the process may be key to understanding why workplace partnership is not viewed in the same positive light as the national process. The process certainly differs from traditional productivity and work organisation agreements that resulted from collective bargaining.

According to the Urban City Council Annual Report the function of PMDS is to design and agree a 'role profile for each employee setting out the key result areas and the objectives/standards required'. All employees are to receive a 'staff profile' containing a 'detailed schedule of staff responsibilities, outlining the specific role of staff in each of their key duties'. These roles are to be reviewed with staff biannually. Individualised feedback on a one-to-one basis for all employees is to be given annually by management. The purpose of the appraisal process is to 'monitor current performance, improve future performance, maintain standards, assess potential, develop individuals' training needs and set agreed targets'. The report states that the impact of the system to date has been that all staff members 'are clear of their role and responsibilities and what is expected from them'; it also states (without more) that 'productivity has increased since the introduction of the appraisal system'.

\subsection{Commitment and control}

A clear majority of respondents in this research (involved in white-collar, semi-skilled work) reported that their workloads were increasing. ${ }^{6}$ It was clear that respondents felt demands put on them at work were escalating; that work was becoming more qualitatively intense:

I suppose that's one of the difficulties of the job. There seem to be more things coming onto our table now that weren't there twenty years ago (Francis).

A key element of reform under the partnership process has been increased interaction with the public and improved service delivery through, inter alia, more flexible working patterns (e.g. longer opening hours) and better 'communication of performance to customers'. Thompson (2003) argues that many jobs (particularly involving service

\footnotetext{
${ }^{6}$ More than half of survey respondents reported, first, that their workload had increased in the last two years and, secondly, that staffing levels in the council were insufficient.

${ }^{7}$ Extracted from the Urban City Council Agreed Action Plan/Progress Report. See also Appendix A and section 28 of Towards 2016.
} 
Table 3: Information provision and employer responsiveness

\begin{tabular}{lcccc}
\hline & $\begin{array}{c}\text { Strongly } \\
\text { agree/ } \\
\text { Agree }\end{array}$ & Undecided & $\begin{array}{c}\text { Disagree/ } \\
\text { disagree }\end{array}$ & Total \\
\hline My employer is responsive to my needs & 10 & 8 & 14 & 32 \\
$\begin{array}{l}\text { I am kept well informed by my } \\
\text { employer about developments at work }\end{array}$ & 8 & 5 & 19 & 32 \\
\hline
\end{tabular}

$n=32$.

provision) have been expanded to include a greater range of tasks, what he refers to as multi-skilling or multi-tasking. Jobs that involve dealing with the public often require greater levels of 'emotion work' (Noon and Blyton, 2002) and so, require more 'bits' of the individual employee to be put into the work. Du Gay (2008) argues it is difficult to underestimate the importance allocated to qualities of 'enthusiasm', 'enterprise' and 'compassion' in recent discourses of public sector organisational reform. This ties in with the idea that the search for 'quality' service provision is likely to require high levels of employee commitment. This may result in greater autonomy for, and an upskilling of, workers. The need for employers to generate commitment to the organisation, on this view, should imply a 'much firmer basis than in the past for a mutuality of interests between labour and management' (Kelly, 1998: 144), less conflict and, therefore, greater scope for consensual employment relations. This will arguably be reinforced where employees feel they have a voice regarding key issues in their working and organisational life (changes in work practices, organisational strategy, etc.). This, of course, is the discourse that surrounds workplace partnership.

Respondents here, however, gave extremely negative responses to survey questions around information provision and responsiveness to employee needs by the employer; a clear majority of council employees felt that the organisation was not communicating with, nor responding to, its staff effectively (Table 3). This finding is strongly reflected by recent national survey data. O'Connell et al. point out that surprisingly high percentages of public sector employees seemed to feel that they were 'hardly ever' provided with information in key areas such as product/service innovation, introduction of new technology, re-organisation of services, or changes to work practices (2004: 16).

It is clear that all employers need to garner some minimum level of commitment from their employees to the organisation or, at least, to the task in hand. Much of the literature on contemporary service sector employment emphasises the need for organisations to 'differentiate' themselves on the basis of 'quality service' and 'customer care' (Bosch and Lehndorff, 2005). Even for the most protected sectors of public service employment 'consumerist' principles and expectations are increasingly relevant to how services are provided (Crouch, 1999). Thus, arguably, the need to generate employee commitment grows ever more acute in such sectors. At the same time, the nature of the business influences how this is achieved. It might be likely that commitment can be generated through individualised pay structures or by granting employees greater 'responsible autonomy' in their work (Noon and Blyton, 2002). However, there is a less benign view of the manner in which employees become more 'embedded' in the organisation. This view highlights that where neo-Taylorist models 
of work organisation have been introduced, flatter organisational structures and relative employee autonomy exist side-by side with increased delegation of responsibility to employees to meet market-determined economic objectives of the employer; this leads to the emergence of '(organisation) dependent independent employees' (Dølvik and Waddington, 2005: 323). Here, employee compliance and direct management control are more likely to feature.

This latter view seems to approximate the 'metrics' approach adopted in the local authority sector. New Public Management research has suggested that performance indicators tend to have an inability to explain why and how certain things happened; they can also result in an excessive focus on what gets measured (and, frequently, this tends to be extremely short-term action). As it is extremely difficult to design a performance measurement model, which adequately captures all aspects of multifaceted work of the types increasingly being done by local authority employees, the introduction of quantitative performance metrics is likely, not to induce greater effort on the part of employees, but rather 'influence their distribution of effort, and of time and attention, among their different responsibilities' (Goldthorpe, 2000: 218). The introduction of controlling benchmarking techniques then, represents a fundamental shift from the 'management by commitment' suggested by the discourse of workplace partnership to the neo-Taylorist 'management by control' approach traditionally used in relation to unskilled employees, like assembly-line workers. Apparently, in return for the pay increases negotiated at national level, local government employees at the workplace are required to work through a (Fordist-like?) list of conditions to be fulfilled in terms of performance measurement. This suggests the possibility that what is happening on the ground in local authorities is more micro-management despite a more multi-faceted workload, and more quantitative targets to be reached despite the qualitative language of 'service', 'quality', and 'inclusion'. Thus, we see the expected relationship between more multi-faceted work and management style inverted; the greater the range of tasks and skills required of local government employees (including more 'emotion' work) the more 'management by control'. This interpretation of events at Urban City Council finds support in the OECD review of the Irish public sector generally:

The Performance Verification Process is, for example, a monitoring mechanism of co-operation, in an industrial relations context, with modernisation processes under the pay agreements, rather than a forum for a holistic review of organisational performance (2008: 29, emphasis added).

This is likely to have important implications for the 'public sector ethos', which may be undermined by such a metrics-based approach (Wickham, 2006). Recent national data found that while four-fifths of respondents professed themselves 'proud to work for (their) organisation', it was public sector workers who were more likely to respond positively (O'Connell et al., 2004: 30). Although council workers may not be felt to embody such an ethos to the extent of, say, nurses or teachers, there was evidence from the respondents that work in local government was seen as having a positive association with public service. One interview respondent, for example, referred to the satisfaction of being able to contribute to solving issues of local public concern:

I always had a great interest in traffic safety generally. (In 1994) I became the county road safety officer here. I really, really enjoy what I'm doing ... I think (that is) worth an awful lot of extra money if you can out a monetary value on it (Francis). 
As Wickham (2006) points out, public sector organisations are part of the common public sphere and exist to service citizens, not customers. Thus, NPM 'accounting techniques' by:

measuring all elements of performance in order to identify the specific public service elements (so that the state can then explicitly pay for them) undermines the general public service ethos of the enterprise (ibid:: 166).

Similarly, Pate et al. (2007) find the most persuasive explanation of the decline of trust in public sector management that they document to be the erosion of the public sector ethos and 'the denigration of public sector ideology and values' (ibid.: 466) represented by senior management commitment to a resource-based view of public sector organisations.

\subsection{National gain for local pain?}

How does this relate to the positive attitudes displayed towards national partnership? Too often in the literature, partnership at national and local level is viewed separately. There is, in relation to public sector partnership, however, a need to explicitly integrate views of both as part of the same system. In this research, virtually all respondents (employees, union representatives and employers) agreed on the success of the partnership process in terms of pay outcomes. Representation in pay negotiations, obviously, remains one of the key determinants of trade union membership. National partnership therefore gives the union movement a very visible and easily identifiable return; periodic wage increases. Conversely, the absence of any local bargaining renders the impact of the local union less discernable. ${ }^{8}$

National social partnership may also be seen to be more acceptable or appealing to stakeholders (including employees) because it at least aspires to fulfil ideas of deliberative democracy. Labour is explicitly and, crucially, publicly, given a 'voice', and is viewed as having political and policy-making 'clout'. This can be seen in the manner in which the contents of the national agreements have been progressively expanded, from an early focus simply on the questions of pay and tax reform, to the plethora of issues that later featured (migration, waste management, alcohol/drug misuse, etc.). Under the various partnership agreements, a host of bodies, working groups, and task forces, on which the unions were represented, were set up (23 under the PPF alone; Turner, 2002) and through the involvement in the process of community and voluntary groups, union representatives have come into contact with a range of other civil society actors. The sense of partnership giving the unions a policy platform beyond the narrow confines of workplace bargaining was alluded to by Brendan (IMPACT workplace representative):

Being promised long-term macroeconomic taxation policy stuff was a new dimension, and in '87 and the early '90s you had to say, 'we're going to have to wait for these tax cuts', and you did have to wait but you did get them. People on both sides did honour their word.

At workplace level, however, the picture is quite different. Here, respondents did not endorse the view that partnership resulted in more 'voice' (particularly in terms of union voice) and, as explained above, micro-management and quantitative targetsetting were increasing. As can be seen from the extract of the Action Plan/Progress

\footnotetext{
${ }^{8}$ This is less of a factor in the public, as opposed to private, sector given the centralised nature of pay determination. Nevertheless, local 'top up' bargaining did occur in the pre-partnership era. 
Report in Appendix A, many of the key commitments agreed in exchange for pay increases remain to be decided at national level (atypical working arrangements, for example) with merely their implementation left to local actors. The extent to which local implementation occurs through partnership is, it seems, variable. Thus, the pay increases negotiated nationally come with attached conditionalities to be worked through at local level, many of which, it seems, are implemented by management 'decree'. One example given by Brendan colourfully bears this out:

The manager, for example, decided he wanted a paper-free, automated environment and he just decreed that, you know ... if anybody had any reservations or objections or suggestions, well, tough. It was coming in and that was it.

This interpretation seemed to be confirmed by Alice (HR representative): 'What has happened with partnership is that management have decided on things that they might want to send to the partnership committee' (emphasis added).

This, again, reflects national trends. The ESRI/NCPP study examined both the type of information available in the workplace and the extent to which workers' views are considered and acted upon. Approximately a quarter of respondents reported that they were 'rarely' or 'almost never' consulted prior to major decisions, provided with feedback on why decisions had been made or, even where prior consultation had taken place, had any attention paid to their views (O'Connell et al., 2004: 95). In Urban City Council, respondents were strongly of the view that workplace partnership initiatives (especially the Workplace Review) had not resulted in their views being taken into account:

We were all asked our views on a whole load of different things, but nothing happened. Maybe that's the problem; nothing ever happens from anything. It's great to talk, it's great to get everybody's views, but if nothing changes then what's the point? (Mandy).

In relation to one key issue of public sector reform, the introduction of PMDS, local partnership did have a role to play in the council. Given that this was identified by management, unions and staff at the time of the research as the main HR issue coming down the line one might have expected partnership to be actively involved in the information and consultation process around the introduction of the system. Instead, according to the partnership facilitator:

partnership will be involved in promoting (PMDS) and explaining what's within it. I think the greatest fear of it by staff would be they see it as a stick coming to beat them. We need to sell it as a means of them identifying areas that would allow them to improve themselves within their work location, and to improve the public service generally beyond that (emphasis added).

Thus, the role of local partnership would be to 'sell' the (seemingly unquestioned) merits of PMDS to staff, rather than actively involving the latter in 'common ownership of the resolution of challenges' (Partnership 2000), or indeed 'the customisation of national policies for local level implementation' (LANPAG Strategic Plan 200305). The discourse of inclusion, participation and deliberative democracy, it seems, arrives at the level of workplace partnership in a highly qualified fashion. Perhaps unsurprisingly, given this, the attempts made to 'sell' the system had not been successful, and there remained significant fear and mistrust amongst staff members:

In HR a lot of the policies and procedures are always bent. People implement them in their own way. You will never have standard across the board and it's the same with PMDS. If someone doesn't like their employee, it's obviously going to work out not in the employee's favour (Geraldine). 
Interestingly, the restricted role for the local partnership committee in relation to a key reform mechanism like PMDS seems to be not untypical of the broader public service. The NCPP review of Civil Service reform identified a number of cases where, while partnership committees had initiated and implemented many policy decisions concerning the work environment, they simply 'undertook a monitoring role when dealing with the PMDS issue' (NCPP, 2003: 5).

A final problem is the thorny issue of the binding arbitration procedure regarding pay compliance clauses introduced as part of Sustaining Progress (which contains binding mechanisms to bring finality to pay disputes) and the fact that all of the partnership agreements contain 'no strike' clauses (see appendix A). For staff and the local union industrial action in respect of any of the conditionalities tied to pay agreements (negotiated, remember, centrally) is not an option.

\section{CONCLUSIONS}

Over the last two decades, social partnership has become institutionalised as the 'normal' method of socio-economic governance in Ireland. As part of the process, issues of public sector pay and modernisation have featured increasingly in the national agreements. The sample in this research is small and we must be careful about generalising. However the case study location was selected as a means of investigating in-depth how the (archetypal) workplace partnership process operates in the local authority sector. Particularly apposite for this research, given the nature of the workforce (white-collar, professional employees who are members of a union noted for its reluctance to engage in traditional collective action) and the nature of public sector clerical/administrative work, is the fact that we would expect these workers to be among the groups most likely to be well-disposed towards a nonconflictual, partnership approach.

The findings here echo national data (Roche, 2007) in indicating that most respondents in this public sector workplace were quite supportive of national level social partnership. However, the data show that there has been a singular failure by the union movement to effectively link the different levels of partnership. Respondents did not see much evidence of a more 'partnership oriented' approach to employeremployee relations, or greater employee participation, and did not see any significant increase in union influence at their workplace.

The findings suggest that partnership at national level has been seen by most respondents as relatively beneficial in terms of pay and the broad economic climate. Clearly, too, the process (at least until the economic turbulence of 2009) has coincided with a period of sustained economic growth. The (relative) satisfaction with, and enhancement of, the trade union movement's national standing, however, must be set against the more negative perception of partnership at the workplace. It seems that in the Irish partnership process the benefits (pay and some level of policy input) accrue at national level, while the costs (conditionalities, binding arbitration, etc.) are felt at local level. In this article, we have, thus, sought to emphasise the (slightly ambiguous) national gains and the (rather more entrenched) local pains of Irish social partnership in the public sector. Here, partnership is an odd case, as it is not truly voluntarist but nor does it operate on a statutory basis. The voluntary national agreements actually set up a 'quasi-statutory' mechanism in the public sector which is tightly linked to the modernisation agenda. The result is that, in terms of modernisation and change, the local union (via workplace partnership structures) simply 'negotiates' for the least bad 
result. Local representatives are required, for example, to bring forward proposals merely as to type of PMDS to be implemented.

The example of this local authority suggests that partnership has resulted in a trade-off of pay increases for, arguably, less employee and union voice at the workplace, with local partnership committees reduced to the role of 'selling' a predetermined reform agenda. The process has been used in a managerialist manner to steer through a public sector reform schedule, which seeks tighter, more controlling management structures, and which risks undermining the core public service ethos. This suggests a version of 'deliberative democracy' that is largely instrumental; the use of partnership as a legitimisation tool. ${ }^{9}$ The union movement, it seems, has singularly failed to adequately link structures of national and workplace partnership. The same cannot be said of the state and employers, who viewed partnership as a vehicle for market-based public sector reform. However, in early 2009, employers, both public and private, decided to freeze all pay rises due under the national social partnership agreement (Sheehan, 2009). This move not only sheds a new light on Teague and Donaghey's (2009) account of Irish partnership as an 'unorthodox system of institutional complementarities', but also questions its future practical use for state officials as a tool to manufacture consent for market-based public sector reform.

\section{References}

Allen, K. (2000), The Celtic Tiger: The Myth of Social Partnership (Manchester, Manchester University Press).

Auer, P. (2000), Employment Revival in Europe (Geneva, ILO).

Baccaro, L. (2002), 'The Constitution of "Democratic" Corporatism in Italy', Politics and Society, 30, 2, 327-357.

Baccaro, L. (2003), 'What is Alive and What is Dead in the Theory of Corporatism?', British Journal of Industrial Relations, 41, 4, 683-706.

Baccaro, L. and M. Simoni (2007), 'Centralised Wage Bargaining and the "Celtic Tiger" Phenomenon', Industrial Relations, 46, 3, 426-455.

Bacon, N. and P. Samuel (2009), 'Partnership Agreement Adoption and Survival in the British Private and Public Sectors', Work, Employment and Society, 23, 2, 231-248.

Black, J., A. Green and P. Ackers (1997), The Demise of Collectivism: Implications for Social Partnership (Wolverhampton, WBS Working Papers Series).

Bosch, G. and S. Lehndorff (2005), Working in the Service Sector: A Tale From Different Worlds (London, Routledge).

Crouch, C. (1999), Social Change in Western Europe (Oxford, Oxford University Press).

D'Art, D. and T. Turner (2002), 'Corporatism in Ireland: A View From Below', in D. D'Art and T. Turner (eds), Irish Employment Relations in the New Economy (Dublin, Blackhall Press) pp. 259-274.

Dølvik, J. E. and J. Waddington (2005), 'Can Trade Unions Meet the Challenge? Unionisation in Marketised Services', in G. Bosch and S. Lehndorff (eds), Working in the Service Sector: A Tale from Different Worlds (London, Routledge) pp. 316-341.

Du Gay, P. (2008), "Without Affection or Enthusiasm": Problems of Involvement and Attachment in "Responsive" Public Management', Organisation, 15, 3, 335-353.

Geary, J. (2006), 'Employee Voice in the Irish Workplace: Status and Prospect', in P. Boxall, P. Haynes and R. Freeman (eds), Employee Voice in the Anglo-American World (Ithaca, NY, Cornell University Press) pp. 97-124.

\footnotetext{
${ }^{9}$ See Bacon and Samuel (2009: 245) for a similar discussion in the UK context.
} 
Geary, J. (2008), 'Do Unions Benefit from Working in Partnership with Employers? Evidence from Ireland', Industrial Relations, 47, 4, 530-568.

Geary, J. and W. K. Roche (2005), 'The Future of Information and Consultation in Ireland', in J. Storey (ed.), Adding Value Through Information and Consultation (Basingstoke, Palgrave) pp. $170-199$.

Geary, J. and W. K. Roche (2006), Partnership at Work: The Quest for Radical Organisational Change (Basingstoke, Routledge).

Goldthorpe, J. H. (2000), On Sociology: Numbers, Narratives and the Integration of Research and Theory (Oxford, Oxford University Press).

Hartley, J. (1994), 'Case Studies in Organisational Research', in C. Cassell and G. Symon (eds), Qualitative Methods in Organisational Research (London, Sage) pp. 208-229.

Hastings, T., T. Sheehan and P. Yeates (2007), Saving the Future: How Social Partnership Shaped Ireland's Economic Success (Dublin, Blackhall).

Kelly, J. (1998), Rethinking Industrial Relations: Mobilisation, Collectivism and Long Waves (London, Routledge).

Mac Sharry, R. and P. White (2001), The Making of the Celtic Tiger: The Inside Story of Ireland's Boom Economy (Cork, Mercier Press).

NCPP (2003), Civil Service Modernisation Using A Partnership Approach (Dublin, NCPP).

NCPP (2005), Workplace Change and Innovation in Ireland's Local Government Sector (Dublin, NCPP).

Noon, M. and P. Blyton (2002), The Realities of Work (Basingstoke, Palgrave).

O'Cinnéide, S. (1998), 'Democracy and the Constitution', Administration, 46, 4, 41-58.

O'Connell, P. J., H. Russell, J. Williams and S. Blackwell (2004), The Changing Workplace: A Survey of Employees' Views and Experiences (Dublin, ESRI/NCPP).

O'Donnell, R. (2000), 'Social Partnership: Principles, Institutions and Interpretations', in P. J. O'Connell (ed.), Astonishing Success-Economic Growth and the Labour Market in Ireland (Geneva, ILO) pp. 52-70.

OECD (2008), Ireland: Towards An Integrated Public Service (Paris, OECD).

Pate, J., P. Beaumont and S. Stewart (2007), 'Trust in Senior Management in the Public Sector', Employee Relations, 29, 5, 458-468.

Power, M. (1997), The Audit Society. Rituals of Verification (Oxford, Oxford University Press).

Roche, W. K. (1999), The End of New Industrial Relations (Florence, EUI Working Papers).

Roche, W. K. (2007), 'Social Partnership in Ireland and New Social Pacts', Industrial Relations, 46, 3, 395-425.

Sheehan, B. (2009), 'National Pay Deal Collapses in Midst of Economic Crisis', Retrieved 4 May 2009 http://www.eurofound.europa.eu/eiro/2009/01/articles/ie0901039i.htm

Tailby, S., M. Richardson, P. Stewart, M. Danford and M. Upchurch (2004), 'Partnership at Work and Worker Participation: An NHS Case Study', Industrial Relations Journal, 35, 5, 403-418.

Teague, P. (2004), 'Social Partnership and the Enterprise: Some Lessons from the Irish Experience', European Political Economy Review, 2, 1, 6-35.

Teague, P. and J. Donaghey (2009), 'Why Has Irish Partnership Survived?', British Journal of Industrial Relations, 47, 1, 55-78.

Thompson, P. (2003), 'Disconnected Capitalism: Or Why Employers Can’t Keep Their Side of the Bargain', Work, Employment and Society, 17, 2, 359-378.

Turner, T. (2002), 'Corporatism in Ireland: A Comparative Perspective', in D. D'Art and T. Turner (eds), Irish Employment Relations in the New Economy (Dublin, Blackhall Press) pp. 275-300.

Wallace, J., P. Gunnigle and G. McMahon (2004), Industrial Relations in Ireland (Dublin, Gill and Macmillan).

Wickham, J. (2006), Gridlock: Dublin's Transport Crisis and the Future of the City (Dublin, TASC/New Island).

Williams, J., S. Blackwell, S. Gorby, P. J. O’Connell and H. Russell (2004), The Changing Workplace: A Survey of Employers' Views and Experiences (Dublin, ESRI/NCPP). 
National and Workplace Partnership

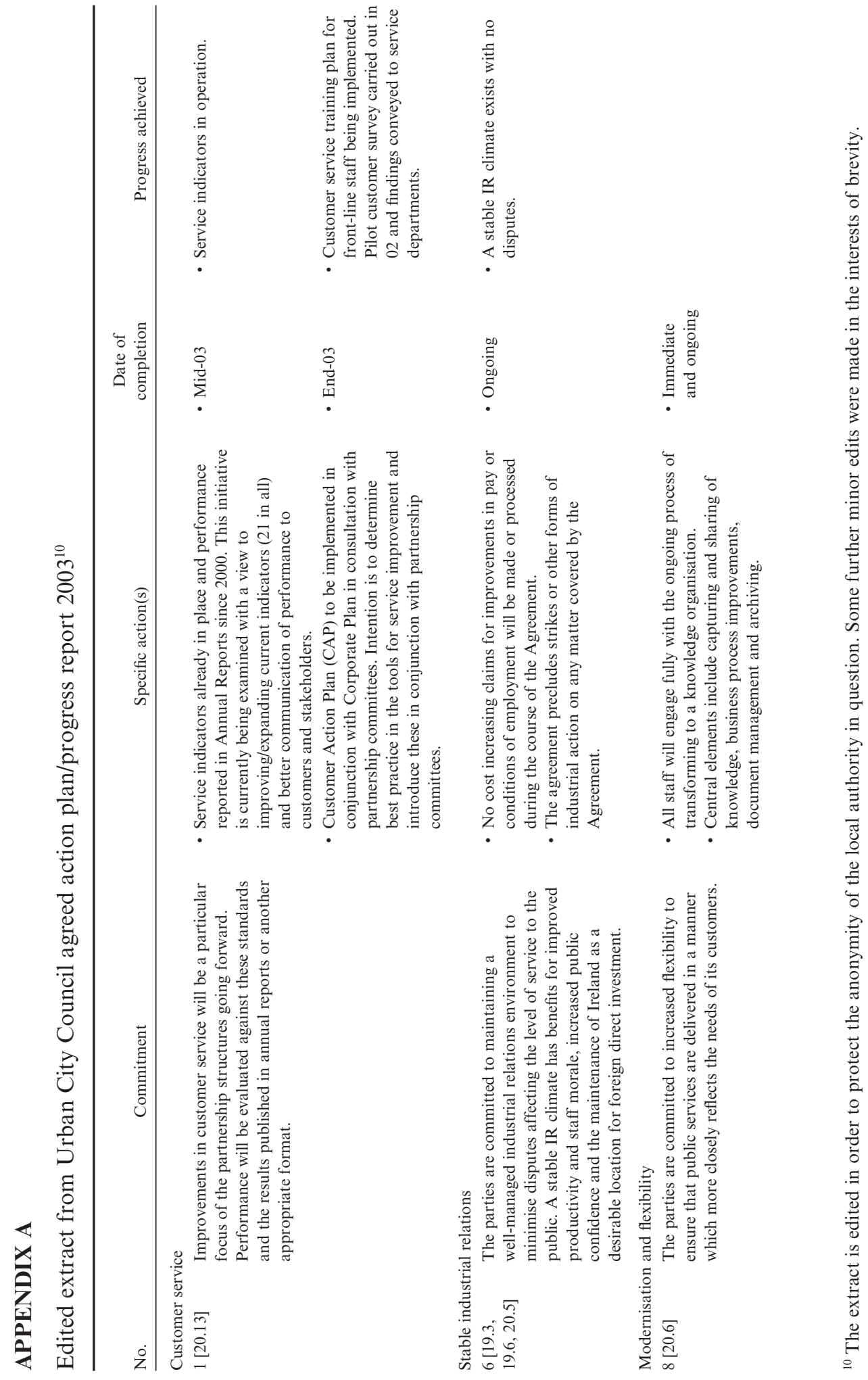

(C) 2010 The Author(s) 


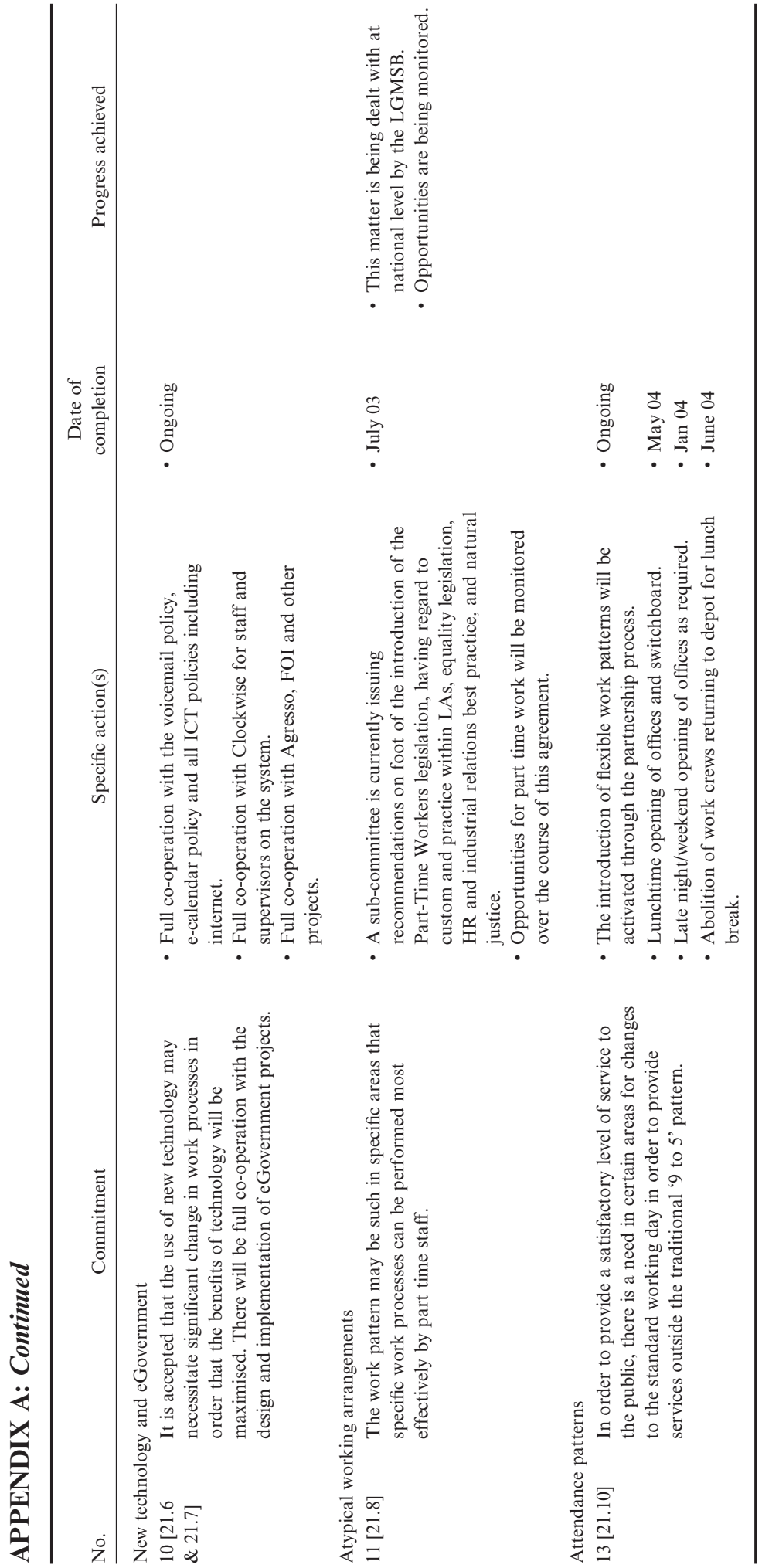


Copyright of Industrial Relations Journal is the property of Wiley-Blackwell and its content may not be copied or emailed to multiple sites or posted to a listserv without the copyright holder's express written permission. However, users may print, download, or email articles for individual use. 